Nevşehir Bilim ve Teknoloji Dergisi Cilt 6(2) 483-493 2017

DOI: 10.17100/nevbiltek.337304

URL: http://dx.doi.org/10.17100/nevbiltek.337304

\title{
Asartepe Baraj Gölü (Ankara) Cyprinus carpio Popülasyonun Bazı Biyolojik Özellikleri
}

\author{
Ömer SAYLAR ${ }^{1, *}$, Göktuğ GÜL ${ }^{2}$, Mehmet YILMAZ $^{3}$, Ali GÜL ${ }^{3}$ \\ ${ }^{1}$ Gazi Üniversitesi, Gazi Eğitim Fakültesi, Fen Bilgisi Eğitimi Anabilim Dalı, Ankara \\ ${ }^{2}$ Gazi Üniversitesi, Sağlık Hizmetleri Meslek Yüksekokulu, Gölbaşı, Ankara \\ ${ }^{3}$ Gazi Üniversitesi, Gazi Eğitim Fakültesi Biyoloji Eğitimi Anabilim Dalı, Ankara
}

$\ddot{O} z$

Bu çalışmada Ankara Asartepe (Çanıllı) Baraj Gölü’nden Mart 2015-Şubat 2016 tarihleri arasında aylık olarak yakalanan Cyprinus carpio türünün bazı morfometrik özellikleri, yaş kompozisyonu, eşey oranı ve kondisyon faktörü incelenmiştir. Çalışmada 40 adet örnek kullanılmıştır Avlanmada balık kepçeleri, farklı göz açıklığındaki fanyalı ağlar ve oltalar kullanılmıştır Tür üzerinden 14 morfometrik ve 10 meristik karakter çalışmada kullanılmıştır. Örneklerin eşey oranı 1:1,67 olarak bulunmuştur. Balıkların yaşlarının

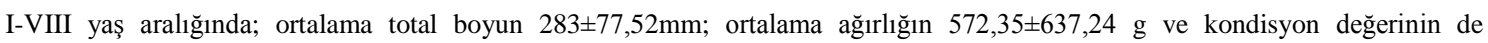
$2,015 \pm 0,27$ arasında olduğu tespit edilmiştir. Boy-ağırlık ilişkisi parametreleri $a=0,0002, b=2,999, r^{2}=0,957$ olarak hesaplanmıştır. Asartepe Baraj Gölü'ndeki C. carpio'da bu verilere göre izometrik bir büyümenin olduğu gözlenmiştir. Biyometrisinde omur sayısı 34 ve linea lateraldeki pul sayısı 36-39 bulunmuştur.

Anahtar Kelimeler: Cyprinus carpio, Büyüme, Kondisyon Faktörü, Metrik ve Meristik Özellikler, Asartepe Baraj Gölü

\section{Some Biological Features of Cyprinus carpio (L., 1758) Population Living in Asartepe Dam Lake (Ankara)}

\begin{abstract}
The study involves the determination of morphologic features, age composition, gender ratio and condition factor of Cyprinus carpio (L., 1758) species caught on monthly basis from Ankara Asartepe Dam Lake between March 2015-February 2016 . The sample was consisted 40 fish species.The fishing process was carried scoops at different sizes, trammel nets with various mesh sizes, hooks and spreading fish nets. The male to female gender distribution ratio of the sample was 1/1.67. The mean total height, weight and condition factor of the samples ranging between I-VIII years of age were $283 \square 77.52 \mathrm{~mm} ; 572.35 \square 637.24 \mathrm{~g}$ and $2.015 \square 0.27$ respectively. The parameters of the length- weight relation were found to be $a=0.0002, b=2.999, r 2=0.957$. These values indicated that the C. carpio population in Asartepe Dam Lake shows an isometric growth. The biometric results showed that the numbers of the samples was 34 and the number of the lateral line scales was between 36-39.
\end{abstract}

Keywords: Cyprinus carpio, Growth, Condition Factor, Metric and Meristic Traits, Asartepe Dam Lake

\footnotetext{
*e-mail: omersaylar50@gmail.com
} 
1. Giriş

Tatlı su balıkları, sucul ekosistemlerin en önemli elemanlarındandır. Çevresel kirliliğin belirlenmesi, izlenmesi ve değerlendirilmesi ile ilgili çalışmaların her zaman konusu olmuştur. Çevresel faktörlerin olumsuz etkileri balıklarda boy ve ağılıkça büyümenin yanında biyometrisine de yansıyarak farklılaşmalara neden olmaktadır. Biyoçeşitlilikte çok önemli bir yeri olan balıkların, biyo-çevreyle olan ilişkilerinin bilinmesi, türün dağılımı ve geleceği açısından önemlidir. Bu bilgiler ayrıca iç sulardan maksimum düzeyde yararlanmayı da kolaylaştırır.

Tatlısu balık familyaları içerisinde Cyprinidae dünya çapında sahip olduğu tür sayısı ile dikkat çekmektedir. Dünya genelinde en büyük tatlısu balık faunası Cyprinidae familyasına ait olup yaklaşık 200’ün üzerinde cinsi ve 2100 civarında türü vardır [1]. Cyprinus carpio L.,1758 (Sazan) asıl dağılış alanı Güneydoğu Asya ve özellikle Çin olan bir türdür. Yapay balık üretiminde önemli yer tutması nedeniyle zamanla tüm dünyaya yayılmıştır. Anadolu'da fazla soğuk olan göl ve göletleri dışında birçok göl, baraj gölü ve nehirlerin durgun akan kısımlarında yayılış göstermektedir [2]. Ayrıca Türkiye, coğrafik konumu sebebiyle $C$. carpio türünün hem yabani hem de doğal stoklarının en güneydeki dağllımlarının belirlenebilmesi için oldukça önemli bir alandır [3].

Türkiye iç sularında, özellikle göl ve göletler ile akarsuların durgun akan kısımlarında geniş bir dağılım gösteren C. carpio ekolojik hoşgörüsü yüksek bir türdür. Sazan balığı yüksek fekondite ve hızlı hareket yeteneklerine sahip olmaları gibi birçok biyolojik özelliklerinden dolayı populasyonlarının hızlı bir şekilde artmasını sağlamaktadır [4 ve 5]. Dolayısıyla fiziksel, kimyasal ve ekolojik özellikleri çok farklı olan su sistemlerine aşılansa bile uyum sorunu yaşamamaktadır. Bu nedenle tüm tatlısu sistemlerine dağılmış durumdadır [2].

Türkiye'nin farklı sucul ekosistemlerinde yoğun şekilde yaşayan C. carpio (L., 1758)'da, yaşboy-ağırlık ilişkisi ile kondisyon faktörü üzerine yapılan çalışmalar, son yıllarda oldukça yoğunluk kazanmıştır [6-13]. Birbirinden farklı sucul ekosistemlerin balık faunasını belirlemek amacıyla yapılmış birçok çalışmada ise C. carpio' nun morfometrik ve meristik özellikleri hakkında bilgiler verilmiştir [1417].

Türkiye'deki birçok farklı su kaynağında yayılmış olarak bulunan C. carpio' nun boy-ağırlık ilişkisi, yaş tayini, kondisyon faktörü ve biyolojisi ile ilgili yapılmış çok sayıda çalışma bulunurken Asartepe Baraj Gölü ile ilgili her hangi bir çalışmaya rastlanmamıştır. Gölde bu tür çalışmaların başlatılması, doğal, istilacı ve ekonomik olan birçok balık türlerinin gölde birlikte bulunması nedeniyle araştırılmaya değer görülmüştür.

Bu çalışmada; Ankara'nın Ayaş ilçesinde bulunan Asartepe Baraj Gölü’ndeki C. carpio popülasyonunun boy-ağırlık ilişkisi, kondisyon faktörü ve bazı diagnostik özelliklerinin belirlenmesi amaçlanmıştır.

\section{Materyal ve Metot}

Çalışma Mart 2015-Şubat 2016 arasında Ankara’ya 50 km uzaklıkta olan Asartepe Baraj Gölü'nden aylık olarak alınan örnekler incelenerek yürütülmüştür. Kirmir Çayı'nın bir kolu olan İlhan Deresi üzerinde sulama amaciyla kurulmuş olan göl, $40^{\circ} 8^{\prime} 42,6624 " \mathrm{~N}$ ve $32^{\circ} 23^{\prime} 49,8156^{\prime \prime} \mathrm{E}$ koordinatlarında bulunur (Şekil 1). Rakımı $825 \mathrm{~m}$, ortalama derinliği $36 \mathrm{~m}$ ve alanı ise $1,77 \mathrm{~km}^{2}$, dir. 
Karasal iklim hüküm sürer ve yıllık ortalama sıcaklığ $11,7^{\circ} \mathrm{C}$ ' dir [18]. Göl, istilacı ve ekonomik balık türlerini birlikte bulundurması açısından önem taşımaktadır. Tinca tinca, Carassius gibelio, Capoeta baliki, Esox lucius, Squalis pursakensis, Vimba vimba, Chondrostoma angorense, Alburnus escherichii, Alburnoides fasciatus, Pseudorasbora parva, Oxynoemacheilus angorae, Cobitis taenia gölde yaşayan diğer balık türleridir.

Gölün kendisinde ve göle dökülen derelerde gerçekleştirilen örnekleme çalışmalarında çeşitli oltalar, kepçeler, serpme ağlar ile göz aralıkları 20x20, 25x25, 30x30 ve 50x50 mm olan fanyalı ağlar kullanılmıştır. Aylık olarak gerçekleştirilen arazi çalışmaları kapsamında gölden 40 adet örnek yakalanmıştır (Şekil 1). Morfometrik ölçümlerde $\pm 1 \mathrm{~mm}$ hassasiyetli cetvel, ağırlık ölçümlerinde ise hassasiyeti $\pm 0.01 \mathrm{~g}$ olan hassas terazi kullanılmıştır. Örneklerin eşeyleri makroskobik olarak belirlenmiş ve en güvenilir oluşum olarak gösterilen omurdan [19], “Chugunova [20]'nın önermiş olduğu yöntem kullanılarak" yaş tayini yapılmıştır.
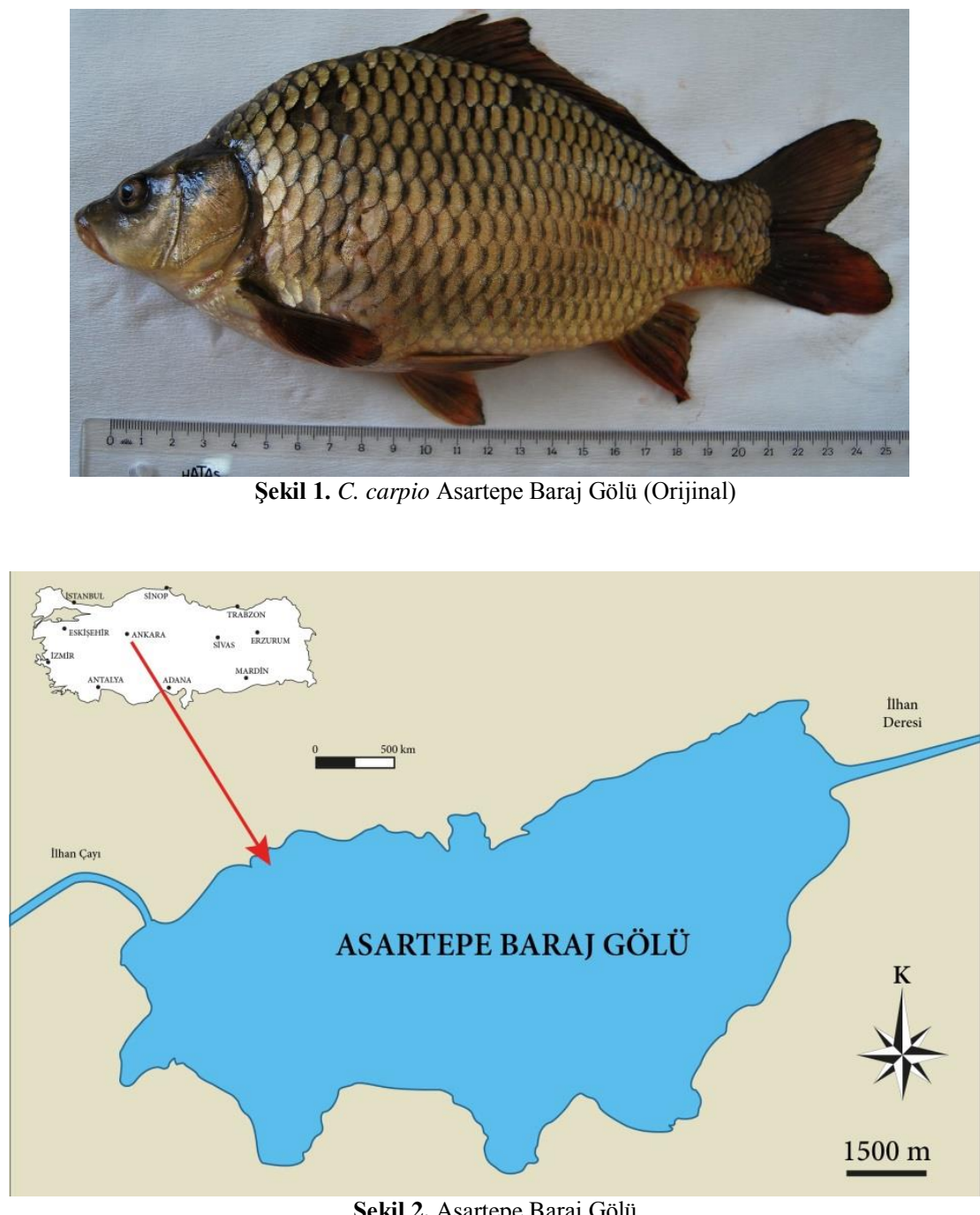

Sekil 2. Asartepe Baraj Gölü

Boy-ağırlık ilişkisi $\mathrm{W}=\mathrm{a} \times \mathrm{L}^{\mathrm{b}}$ formülü; ( $\mathrm{W}=$ balığın ağırlığı $(\mathrm{g})$, a ve b ilişki sabitleri) [21] ve kondisyon faktörü $\mathrm{K}=\mathrm{W} / \mathrm{L}^{3} \times 100$ formülü ; $(\mathrm{KF}=$ kondisyon faktörü, $\mathrm{L}=$ balık boyu) kullanılarak hesaplanmıştır [22]. Morfometrik ve meristik özelliklerin varyasyon katsayıları \%VK= SS/X x100 ( SS= 
Standart Sapma, X Aritmetik Ortalamayı İfade etmektedir) ile bazı diagnostik özelliklerin standart boya oranları hesaplanmıştır. Boy-ağırlık ilişkileri ve kondisyon faktörleri hem eşeylere göre ayrı ayrı hem de birlikte değerlendirilmiştir. Ayrıca örneklerin eşeylerine göre yaş, boy ve ağırlık dağılımları belirlenmiştir. Hesaplamalarda total boy kullanılmıştır.

\section{Bulgular}

\subsection{Morfometrik ve Meristik Özellikler}

İncelenen $C$. carpio bireylerinin morfometrik ve meristik özelliklerine ait değerlerin dağılımı Tablo 1' de verilmiştir.

Tablo 1. Asartepe Baraj Gölü’ndeki C. carpio'nun morfometrik ve meristik özellikleri

\begin{tabular}{|c|c|c|c|c|}
\hline Morfometrik özellikler (mm) & Dağılım & Ortalama & SS & VK $(\%)$ \\
\hline Total boy (TB) & $190-530$ & 283,0 & 77,518 & - \\
\hline Standart boy (SB) & $165-435$ & 235,38 & 67,173 & - \\
\hline Çatal boy (ÇB) & $180-461$ & 254,9 & 71,234 & - \\
\hline Vücut yüksekliği & $76-185$ & 104,45 & 26,236 & 25,12 \\
\hline Baş uzunluğu & $48-121$ & 67,58 & 18,479 & 27,34 \\
\hline Burun uzunluğu & $18-38$ & 23,18 & 6,007 & 25,91 \\
\hline Göz çapı & $7-22$ & 10,15 & 2,641 & 26,01 \\
\hline Postorbital baş uzunluğu & $24-61$ & 33,98 & 9,566 & 28,15 \\
\hline Dorsal mesafe & $72-210$ & 113,35 & 36,562 & 32,25 \\
\hline Dorsal yüzgeç uzunluğu & $13-65$ & 32,5 & 9,674 & 29,76 \\
\hline Ventral yüzgeç uzunluğu & $25-71$ & 38,075 & 10,875 & 28,56 \\
\hline Anal yüzgeç uzunluğu & $24-63$ & 36,1 & 9,488 & 26,28 \\
\hline Kuyruk Sapı Yüksekliği & $25-99$ & 45,82 & 14,913 & 32,54 \\
\hline Kuyruk Sapı Uzunluğu & $31-110$ & 49,82 & 17,762 & 35,65 \\
\hline \multicolumn{5}{|l|}{ Meristik özellikler } \\
\hline Linea lateral (L. lat.) pul sayısı & $36-39$ & 37,7 & 0,9114 & 2,41 \\
\hline Dorsal yüzgeç dallanmamış ışın sayısı & $3-4$ & 3,6 & 0,4961 & 13,78 \\
\hline Dorsal yüzgeç dallanmış ışın sayısı & $19-21$ & 19,6 & 0,4961 & 2,53 \\
\hline Anal yüzgeç dallanmamış ışın sayısı & $2-3$ & 2,87 & 0,3386 & 11,80 \\
\hline Anal yüzgeç dallanmış ışın sayısı & $5-6$ & 5,74 & 0,4423 & 7,70 \\
\hline Pektoral yüzgeç dallanmamış ışın sayısı & $1-2$ & 1,1 & 0,3038 & 27,62 \\
\hline Pektoral yüzgeç dallanmış ışın sayısı & $13-17$ & 13,67 & 0,4743 & 3,47 \\
\hline Ventral yüzgeç dallanmamış ışın sayısı & $1-2$ & 1,75 & 0,4385 & 25,06 \\
\hline Ventral yüzgeç dallanmış ışın sayısı & $7-9$ & 7,77 & 0,4229 & 5,44 \\
\hline Omur sayısı & $33-35$ & 34,05 & 0,5038 & 1,48 \\
\hline
\end{tabular}

Morfometrik özelliklerden en yüksek varyasyonun \%35,65 ile kuyruk sap1 uzunluğu ve en düşük varyasyonun \%25,11 ile vücut yüksekliği olduğu belirlenmiştir. Meristik özelliklerden en yüksek varyasyonun pektoral yüzgeç dallanmamış 1şın sayısı $(\% 27,27)$, en düşük olarak ise \%1,47 ile omur sayısında olduğu tespit edilmiştir.

SB: 235,35 (165-435) mm, SB/VY: 2,25 (2,17-2,35), SB/BU: 3,48 (3,43-3,56), SB/BrU:10,18 (9,16-11,44), SB/GÇ: 21,48 (19,77-23,19), SB/PBU: 6,93 (6,87-7,13), SB/DM: 2,18 (2,07-2,29), SB/DYU: 9,69 (6,69-12,69), SB/VYU: 6,18 (6,13-6,60), SB/AYU: 6,89 (6,87-6,90), SB/KSY: 5,13 
(4,39-6,60), SB/KSU: 4,72 (3,95-5,32), BU/BrU: 2,91 (2,66-3,18), BU/GÇ: 6,66 (5,50- 6,85), D: III-IV, 19-21, A: II-III, 5-6, P: I-II, 13-17, V: I-II, 7-9, L.L: 36-39, LLÜ: 5-7, LLA: 5-7, OS: 34 (33-35).

Diagnostik özelliklerde standart boy ile diğer vücut ölçülerinin oranlaması yapılmıştır. Bu oranlamalar sonunda en yüksek değer olarak, göz çapının standart boya oranında $(21,48)$, en düşük değer ise dorsal mesafenin standart boya oranlamasıyla ( 2,18) bulunmuştur. Yanal çizgideki pul sayısı 37,7 (36-39), omur sayısı 34 (33-35)'dür.

\subsection{Yaş ve Eşey Kompozisyonu}

Asartepe Baraj Gölü'nden yakalanan 40 adet C. carpio bireyinin \%37,5 dişi ve \%62,5’u erkek bireyden oluşmaktadır. Bu çalışmada dişi: erkek oranı 1: 1,67 olarak bulunmuştur. Yaşlara göre eşey dağılımı Tablo 2' de verilmiştir.

Tablo 2. Asartepe Baraj Gölü’ndeki C. carpio 'da Yaș ve Eşey Dağılımı

\begin{tabular}{|c|c|c|c|c|c|c|}
\hline \multirow[b]{2}{*}{ Yaş } & \multicolumn{2}{|c|}{ Dişi } & \multicolumn{2}{|c|}{ Erkek } & \multicolumn{2}{|c|}{ Dişi + Erkek } \\
\hline & $\mathbf{N}$ & $\%$ & $\mathbf{N}$ & $\%$ & $\mathbf{N}$ & $\%$ \\
\hline I & 5 & 12,5 & 5 & 12,5 & 10 & 25 \\
\hline II & 5 & 12,5 & 9 & 22,5 & 14 & 35 \\
\hline III & 1 & 2,5 & 5 & 12,5 & 6 & 15 \\
\hline IV & 0 & 0 & 3 & 7,5 & 3 & 7,5 \\
\hline $\mathbf{V}$ & 3 & 7,5 & 0 & 0 & 3 & 7,5 \\
\hline VI & 0 & 0 & 1 & 2,5 & 1 & 2,5 \\
\hline VII & 1 & 2,5 & 0 & 0 & 1 & 2,5 \\
\hline VIII & 0 & 0 & 2 & 5 & 2 & 5 \\
\hline Toplam & 15 & 37,5 & 25 & 62,5 & 40 & 100 \\
\hline
\end{tabular}

Yaş dağılımı I-VIII yaş arasındadır. 0 yaşında örnek bulunmamaktadır. Dişilerde 5'er adet örnek ile I ve II yaş grubu baskın olarak bulunmuştur. Erkelerde ise 9 adet örnek ile II yaş grubu baskındır $(\% 22,5)$.Genel dağılımda ise en baskın grup yine II yaştır (\%35). Örnekler içinde IV ve VI yaşında dişi, V ve VII yaşında da erkek birey yoktur. Diğer yaş gruplarında, dişi: erkek oranı en düşük $(\% 0,2)$ III yaş grubunda, en yüksek değer ise (\%1) I yaş grubunda bulunmuştur.

\subsection{Yaş-Boy Dağılımı}

Örneklerin yaşlara göre boy dağılımı Tablo 3' te verilmiştir.

Tablo 3. Asartepe Baraj Gölü'ndeki C. carpio 'da Yaş ve Toplam Boy Dağılımı

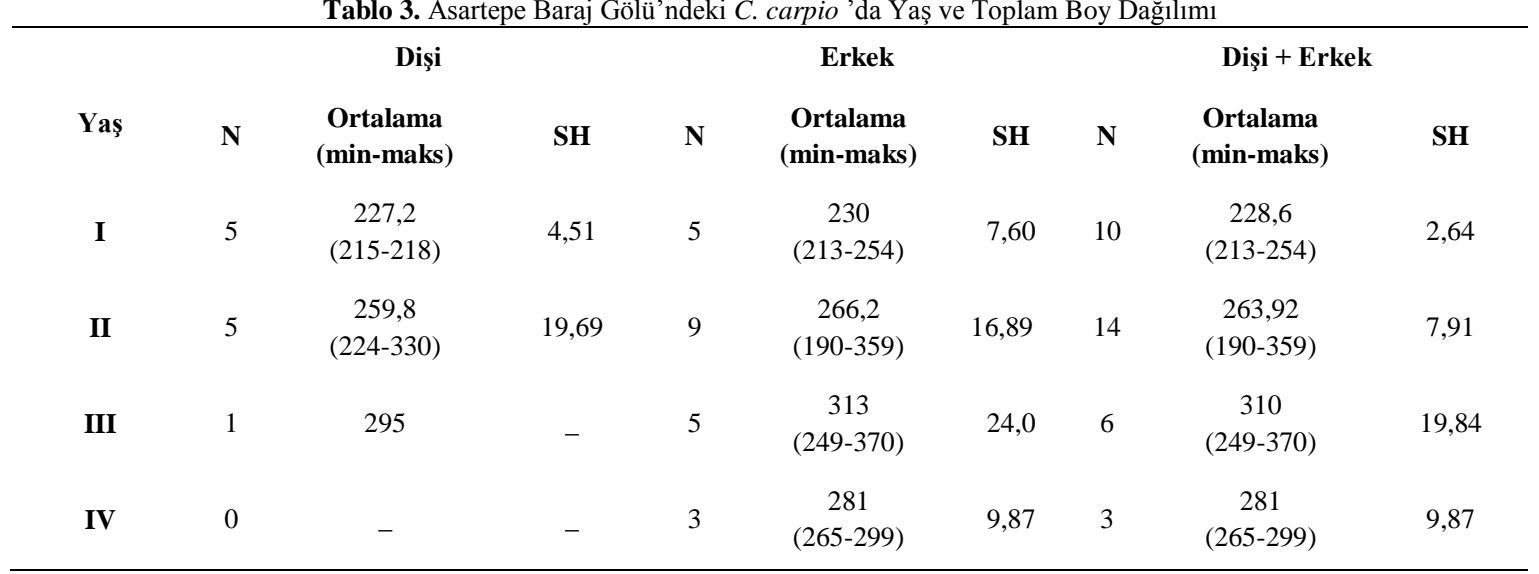


Saylar Ö., Gül G., Yılmaz M., Gül A.

\begin{tabular}{|c|c|c|c|c|c|c|c|c|c|}
\hline $\mathbf{V}$ & 3 & $\begin{array}{c}347,6 \\
(275-493)\end{array}$ & 7,27 & 0 & - & - & 3 & $\begin{array}{c}347,6 \\
(275-493)\end{array}$ & 7,27 \\
\hline VI & 0 & - & - & 1 & 255 & - & 1 & 255 & - \\
\hline VII & 1 & 498 & - & 0 & - & - & 1 & 498 & - \\
\hline VIII & 0 & - & - & 2 & $\begin{array}{c}420 \\
310-530\end{array}$ & 110,3 & 2 & $\begin{array}{c}420 \\
(310-530)\end{array}$ & 110,32 \\
\hline Toplam & 15 & $\begin{array}{c}284,7 \\
215-498\end{array}$ & 2,36 & 25 & $\begin{array}{c}281,9 \\
(190-530)\end{array}$ & 1,39 & 40 & $\begin{array}{c}283 \\
(190-530)\end{array}$ & 12,26 \\
\hline
\end{tabular}

\subsection{Yaş-Ağırlık Dağılımı}

Örneklerin eşeylere göre ağırlık dağılımları tablo 4'te verilmiştir. Aynı yaş gurubunda bulunan dişi ve erkek bireylerin ağırlık dağılımları boy dağılımlarında olduğu gibi birbirine yakındır.

Tablo 4. Asartepe Baraj Gölü’ndeki C. carpio 'da Yaş ve Ağırlık Dağılımı Kompozisyonu

\begin{tabular}{|c|c|c|c|c|c|c|c|c|c|}
\hline & & Dişi & & & Erkek & & & Dişi + Erkek & \\
\hline Yaş & $\mathbf{N}$ & $\begin{array}{c}\text { Ortalama } \\
\text { (min-maks) }\end{array}$ & SH & $\mathbf{N}$ & $\begin{array}{c}\text { Ortalama } \\
\text { (min-maks) }\end{array}$ & SH & $\mathbf{N}$ & $\begin{array}{c}\text { Ortalama } \\
\text { (min-maks) }\end{array}$ & SH \\
\hline I & 5 & $\begin{array}{c}247 \\
(195-277)\end{array}$ & 14,35 & 5 & $\begin{array}{c}248,4 \\
(177-348)\end{array}$ & 29,26 & 10 & $\begin{array}{c}247,7 \\
(177-348)\end{array}$ & 15,33 \\
\hline II & 5 & $\begin{array}{c}376 \\
(155-796)\end{array}$ & 117,93 & 9 & $\begin{array}{c}407,88 \\
(170-876)\end{array}$ & 77,16 & 14 & $\begin{array}{c}396,5 \\
(155-876)\end{array}$ & 62,42 \\
\hline III & 1 & 435 & - & 5 & $\begin{array}{c}712,4 \\
(266-1073)\end{array}$ & 162,3 & 6 & $\begin{array}{r}666,16 \\
(266-1073)\end{array}$ & 140,57 \\
\hline IV & 0 & - & - & 3 & $\begin{array}{c}436 \\
(399-456)\end{array}$ & 18,53 & 3 & $\begin{array}{c}436 \\
(399-456)\end{array}$ & 32,07 \\
\hline $\mathbf{V}$ & 3 & $\begin{array}{c}911 \\
(395-1902)\end{array}$ & 496,22 & 0 & - & - & 3 & $\begin{array}{c}911 \\
(395-1902)\end{array}$ & 496,22 \\
\hline VI & 0 & - & - & 1 & 347 & - & 1 & 347 & - \\
\hline VII & 1 & 2833 & - & 0 & - & - & 1 & 2833 & - \\
\hline VIII & 0 & - & - & 2 & $\begin{array}{c}1824,5 \\
(640-3009)\end{array}$ & 1188 & 2 & $\begin{array}{r}1824,5 \\
(640-3009)\end{array}$ & 1188 \\
\hline Top & 15 & $\begin{array}{c}607,73 \\
(155-2833)\end{array}$ & 194,48 & 25 & $\begin{array}{c}551,16 \\
(170-3009)\end{array}$ & 114,56 & 40 & $\begin{array}{c}572,37 \quad(155- \\
3009)\end{array}$ & 100,83 \\
\hline
\end{tabular}

\subsection{Boy-A ğırlık Dağılımı ve Kondisyon Faktörü}

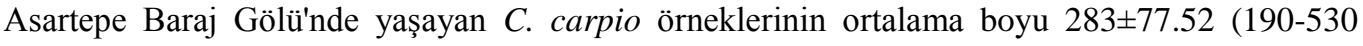

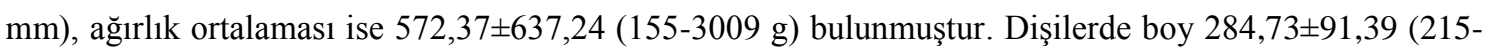

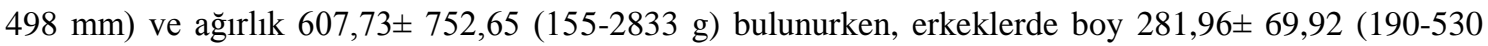

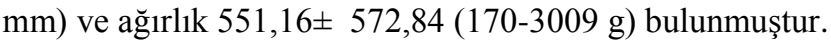

Türün kondisyon faktörü dişilerde $1,977 \pm 0317$ (1,121-2,364), erkeklerde 2,038 $\pm 0,248$ (1,4922,478 ), populasyon genelinde ise 2,015 $0,27(1,121-2,478)$ olarak hesaplanmıştır (Tablo 5). 
Tablo 5. C. carpio'nun boy-ağırlık ilişkisi tanımlayıcı istatistiksel parametreleri ve kondisyon faktörü

\begin{tabular}{|c|c|c|c|c|c|c|c|}
\hline \multirow[b]{2}{*}{ Eşey } & \multirow[b]{2}{*}{$\mathbf{N}$} & \multirow{2}{*}{$\begin{array}{c}\text { Total Boy (mm) } \\
\begin{array}{c}\text { Ort } \pm \text { SS } \\
(\min -\max )\end{array}\end{array}$} & \multirow{2}{*}{$\begin{array}{l}\text { A ğırlık (g) } \\
\text { Ort } \pm \text { SS } \\
(\min -\max )\end{array}$} & \multicolumn{3}{|c|}{ Boy-Ağırlık Parametreleri } & \multirow{2}{*}{$\begin{array}{c}\text { Kondisyon } \\
\text { Faktörü } \\
\text { Ort } \pm \text { SS } \\
(\min -\max )\end{array}$} \\
\hline & & & & a & $\mathrm{b}$ & $\mathrm{r}^{2}$ & \\
\hline Dişi & 15 & $\begin{array}{c}284,73 \pm 91,39 \\
(215-498)\end{array}$ & $\begin{array}{c}607,73 \pm 752,67 \\
(155-2833)\end{array}$ & 0,0201 & 2,990 & 0,949 & $\begin{array}{c}1,977 \pm 0,317 \\
(1,121-2,364)\end{array}$ \\
\hline Erkek & 25 & $\begin{array}{c}281,96 \pm 69,92 \\
(190-530)\end{array}$ & $\begin{array}{c}551,16 \pm 572,84 \\
(170-3009)\end{array}$ & 0,0199 & 3,005 & 0,964 & $\begin{array}{c}2,038 \pm 0,248 \\
(1,492-2,478)\end{array}$ \\
\hline Dişi+Erkek & 40 & $\begin{array}{l}283 \pm 77,52 \\
(189-542)\end{array}$ & $\begin{array}{c}572,35 \pm 637,24 \\
(155-3009)\end{array}$ & 0,0002 & 2,999 & 0,957 & $\begin{array}{c}2,015 \pm 0,274 \\
(1,121-2,478)\end{array}$ \\
\hline
\end{tabular}

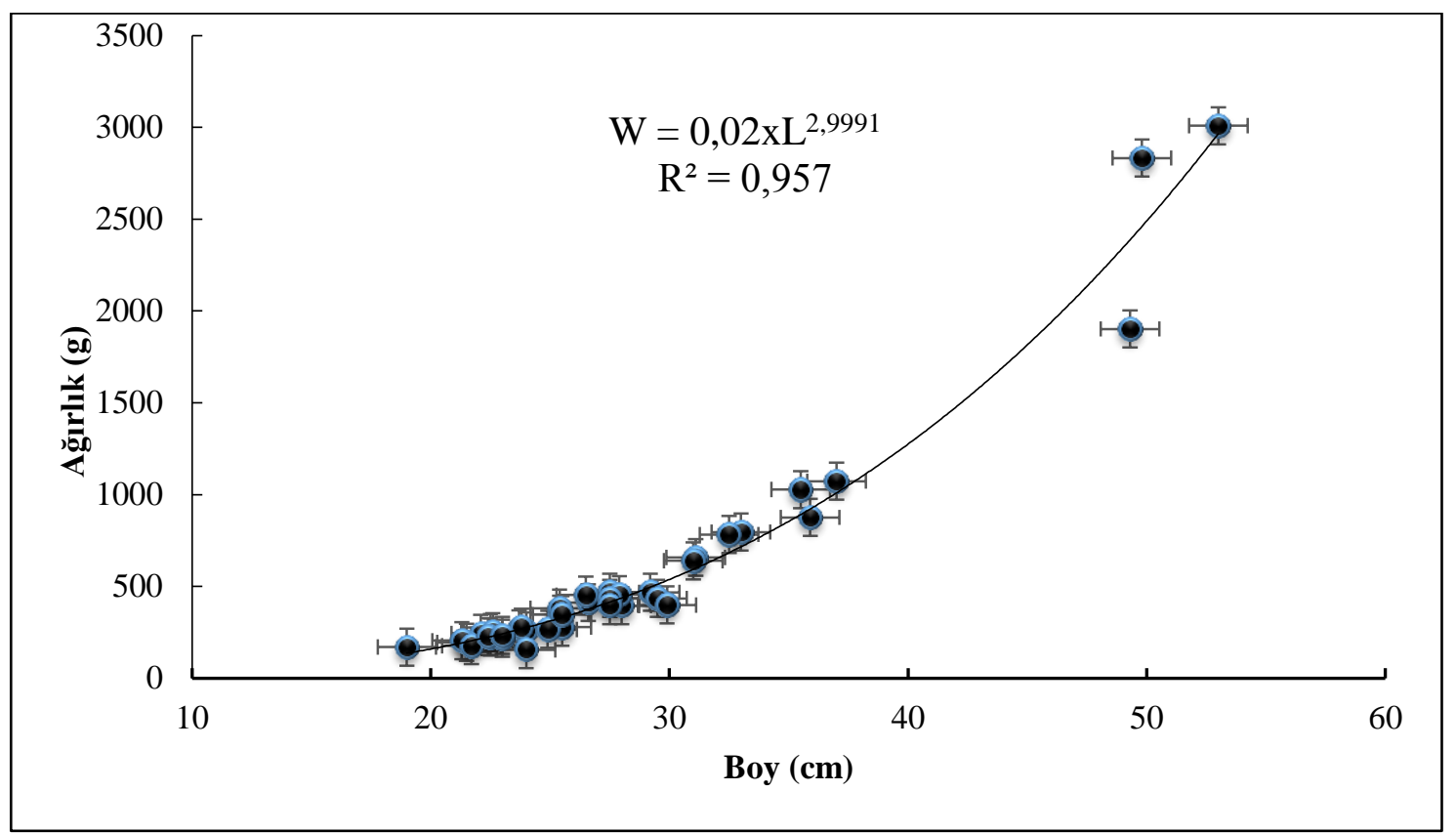

Şekil 3. Asartepe Baraj Gölü’ ndeki C.carpio'da boy-ağırlık ilişkisi

Boy-ağırlık ilişkisi parametreleri $\mathrm{W}=0,02 \times \mathrm{TL}^{2,9991}$ ve korelasyon değeri $\mathrm{r}^{2}=0,957$ olarak hesaplanmıştır.

\section{Sonuç ve Tartışma}

Yoğun bir şekilde balıkçılık faaliyetlerinin gerçekleştirilmiş olduğu Asartepe Baraj Gölü'nde limnolojik etüt çalışmaları sonucunda göldeki mevcut balık popülasyonları, gümüş $\% 50$, barbus $\% 3$, in balı̆̆ $\% 40$, tatlısu kefali $\% 7$ olarak belirlenmiştir. Daha sonra bu mevcut populasyonlar dikkate alınarak rezervuarın kültür sazanı ile balıklandırılması uygun görülmüştür [23]. Günümüzde ise aynalı sazan, pullu sazan, tatlısu kefali, kadife ve turna,gölde bulunan balık türlerinden bazılarıdır [24].

Asartepe Baraj Gölü' nden yakalanan C. carpio bireylerinin \% 62,5'i erkek, \% 37,5'i dişidir. Dişi / erkek oranı 0,6'dır. Beyş̧ehir Gölü’nde \% 40,9 dişi, \% 59,1 erkek, D/E:0,6 [25]; Hirfanlı Baraj Gölü’nde \% 48,0 dişi, \% 52,0 erkek D/E:0,9 [9]; İznik Gölü’nde, \% 53,8 dişi, \% 46,2 erkek, D/E:1,1 [26]; Bafra Balık Göllerinde \% 52,25'i dişi, \% 47,75'i erkek D/E:1 [27]; Damsa Baraj Gölü’nde \% 39,38'i dişi, 
\% 60,62'i erkek, D/E:0,6 [28] olarak bildirilmiştir. Balıklarda eşey oranının türden türe, aynı türün populasyonları arasında ve aynı populasyonda yıldan yıla değişkenlik gösterdiği bilinmektedir [29]. Diğer çalışmalar ile karşılaştırıldığında mevcut farklılığın avlanmanın daha çok üreme mevsiminde yapılmış olabileceği ve değerlerin yüksek olmasının bundan kaynaklandığı düşünülmektedir. Gölde bu tür çalışmaların başlatılması, doğal, istilacı ve ekonomik olan birçok farklı balık türünün gölde birlikte bulunması sebebiyle araştırılmaya değer görülmüştür.

Asartepe sazan popülasyonu yaş kompozisyonu I-VIII yaş grupları arasında dağılım göstermiştir. 0 yaşında örnek çalışmada tespit edilememiştir. Ayrıca örnekler arasında IV, VI ve VIII yaşında dişi, V ve VII yaşında da erkek birey bulunmamaktadır. Asartepe Baraj Gölü sazan popülasyonunda II. yaş grubu bireyler baskındır. Yaş büyüdükçe birey sayısı da azalmaktadır. Bu durumun sazan popülasyonu üzerindeki aşırı avlanmadan kaynaklandığı düşünülmektedir. Popülasyon üzerindeki av baskısı da stoktaki yaşlı bireylerin azalmasına neden olmaktadır [10]. Farklı habitatlardaki C. carpio popülasyonunun yaş aralığı; Gölhisar Gölünde I-VI [6]; Beyşehir Gölü’nde I-XI [25]; Hirfanlı Baraj Gölü’nde I-IX [9];Işıklı Gölü’nde I-XIV [10]; Damsa Baraj Gölünde I-VIII [28] olarak belirtilmiştir.

C. carpio bireylerinin diagnostik özellikleri; D III-IV 19-21, A II-III 5-6, P I-II 13-17, V I-II 7-9, LL 36-39, LT 5-7/5-7 ve omur sayısı 34 olarak bulunmuştur. Çakmak Baraj Gölü'nde D IV 19-20, A III 5, P I 15, V II 8, LL 38-39, LT 6/5-6 [15]; Dalaman Çay1'nda D III-IV 16-22, A II-III 5-6, P I 15-17, V II 7-8, LL 35-40 [30]; Orta ve Yukarı Ceyhan Havzası'nda D III 18-19, A II 5, P I 16-120, V I 8, LL 38-40 [31]; Apolyont Gölü'nde D III-IV 18-20, A II-III 5-6, P I 14-17, V I-II 7-8, LL 35-38, LT 5-6/5-7 [32]; Çamlıgöz Baraj Gölü’nde D III 18-20, A IIII 5-6, P I 14-16, V II 7-8, LL 34-38, LT 6-7/5-6 [33]; Uzunçayır Baraj Gölü’nde D III-IV 20-21, A III, 5-6, P I-II 14-18, V II 8-9 [34] olarak bildirilmektedir. Buna göre Asartepe Baraj Gölü'ndeki C. carpio'da tespit edilen biyometrik veriler, diğer su sistemlerinin sonuçlarıyla karşılaştırıldığında özellikle meristik özellikler açısından benzerlik gösterdiği görülmektedir.

Asartepe Baraj Gölü’ndeki sazan popülasyonunda korelasyon değerinin de, diğer su sistemlerindeki sonuçlarla benzerlik gösterdiği görülmüştür. Ancak omur sayısının, bazı farklı su sistemleri ile değişiklik gösterdiği saptanmışsır. Bu çalışmada omur sayısı 34 (33-35) olarak belirlenmiştir. Büyük Menderes Havzasında [35] belirlenen omur sayıları (36-37), bu çalışmadan daha yüksektir. Bu duruma, populasyonların genetik yapıları ile habitatların su kalite parametrelerinin etkili olabileceği düşünülmektedir.

Boy-ağıllık ilişkisinde populasyon özellikleri hakkında bilgi edinmek için hesaplanan b değeri, balı̆̆ın habitatına ve vücut şekline ilişkin bilgi vermektedir. Ayrıca farklı akuatik ortamlardaki populasyonların karşılaştırılmasında da bu değerden yararlanılmaktadır. Bu değerin 2,5-3,5 arasında olması büyümenin normal olduğunu, $\mathrm{b}<3$ olması ise negatif allometrik bir büyümenin olduğunu belirtmektedir [21]. Asartepe Baraj Gölü’nde bulunan b (2,9991) değerinin 3'e yakın oluşu büyümenin izometrik olduğunu göstermektedir. Bu değer Mogan Gölü [36] ile Damsa Baraj Gölü [28] değerleri ile benzer; Almus Baraj Gölü [37] değerinden düşük, Hirfanlı Baraj Gölü’nde [9] bulunan değerlerden de yüksektir.

Toplam 2,015 0,27SS (1,121-2,478) olarak hesaplanan kondisyon faktörü; Gölhisar Gölü’nde 1,60 [6]; Gelingüllü Baraj Gölü’nde 2,34 [38]; Bayramiç Gölü’nde 2,66 [39]; Karamık Gölü’nde 2,02 [7]; Almus Baraj Gölü'nde 1,33 [37]; Hirfanlı Baraj Gölü'nde 1,42 [9]; Bafra Balık Gölleri’nde 1,87 [27]; 
Çamlıgöze Baraj Gölü’nde 1,64 [33] ve Damsa Baraj Gölü’nde 1,62 [28] olarak belirtilmektedir. Bu çalışmada hesaplanan kondisyon faktörü, Almus, Gölhisar, Hirfanlı, Çamlıgöze ve Damsa Baraj Gölleri değerlerinden yüksek, Bayramiç ve Gelingüllü Baraj Gölü değerlerinden düşük, Karamık Gölü değerleriyle de benzerlik göstermektedir.

Sucul ekosistemlerde ihtiyofauna üzerinde yapılan bu tip çalışmalardan elde edilen sonuçlar popülasyonlardaki değiş̧imleri açıklama ve biyolojik izleme çalışmaları açısından önem taşımaktadır. Asartepe Baraj Gölü C. carpio bireylerinde vücutta yandan yassılaşmanın ve vücut yüksekliğinin diğer sulardaki bireylere göre fazla olduğu tespit edilmiştir. Çok önemli görülen bu morfolojik farklılaşmanın takip edilmesi ve farklı su sistemlerindeki bireyler ile birlikte izlenmesi yararlı olacaktır.

Asartepe Baraj Gölü’nden örneklenen C. carpio' nun metrik-meristik özelliklerinin, boy-ağırlık ilişkilerinin, yaş kompozisyonun ve kondisyon faktörünün belirlenmiş olduğu herhangi bir çalışma mevcut değildir. Türkiye tatlısu kaynaklarında ticari açıdan oldukça önemli olarak değerlendirilen ve balıkçılık baskısı ile karşı karşıya olan sazan balığının hem biyolojik hem de ekolojik özelliklerinin bilinmesi gerçekleştirilecek olan çalışmalara ışık tutacaktır. Ayrıca türün birlikte yaşadığı diğer balık türleri ile etkileşimlerinin değerlendirilmesi adına bir basamak görevi görecektir.

\section{Kaynaklar}

[1] He. S, RL. Mayden, X. Wang, W. Wang, KL. Tang, WJ. Chen, Y. Chen. 2008. Molecular phylogenetics of the family Cyprinidae (Actinopterygii: Cypriniformes) as evidenced by sequence variation in the first intron of S7 ribosomal protein-coding gene: Further evidence from a nuclear gene of the systematic chaos in the family Elsevier Molecular Phylogenetics and Evolution 46: 818-829.

[2] Geldiay R., Balık S. (2007). Türkiye Tatlısu Balıkları. Ege Üniversitesi Su Ürünleri Fakültesi Yayınları, No:46, 644 s, Bornova, İzmir.

[3] Vilizzi L., Ekmekçi F. G., Tarkan A. S., Jackson Z. J., 2014. Growth of common carp Cyprinus carpio in Anatolia (Turkey), with a comparation to native and invasive areas worldwide.Ecology of Freshwater Fish, doi: 10.1111/eff.12141

[4] Ricciardi A, Rasmussen JB 1998. Predicting the identity and impact of future invaders: a priority for aquatic resource management. Can J Fish Aquat Sci 55: 1759-1765

[5] Koehn JD 2004. Carp (Cyprinus carpio) as a powerful invader in Australian waterways. Freshw Biol 49:882-894.

[6] Alp A., Balık S. (2000). Growth conditions and stock analysis of the carp (Cyprinus carpio, Linnaeus1758) population in Gölhisar Lake, Turkish Journal of Zoology, 24: 291-304.

[7] Balık İ, Çubuk H, Özkök R, Uysal R. (2006). Some characteristics and size of carp (Cyprinus carpio L., 1758) population in the Lake Karamık (Afyonkarahisar/Turkey). Turk J Fish Aquat Sci. 6(2):117-122.

[8] Demirkalp F.Y. (2007). Growth characteristics of carp (Cyprinus carpio L., 1758) in Liman Lake (Samsun, Turkey), Hacettepe Journal of Biology and Chemistry. 35 (1): 1-8.

[9] Yılmaz M., Gül A., Saylar Ö. (2007). Hirfanlı Baraj Gölü (Kırşehir)'nde yaşayan Cyprinus carpio L.,1758'nun büyüme özellikleri, GÜ Gazi Eğitim Fakültesi Dergisi, 27 (1): 37-57. 
[10] Yağcı A, M., Alp A., Yeğen V., Uysal R., Yağcı A., Ceylan M. (2008a). Işıklı Gölü’ndeki (Çivril-Denizli) Sazan Populasyonu (Cyprinus carpio L., 1758)'nun Büyüme Özellikleri. E.Ü. Su Ürünleri Dergisi. 25 (4):337-341.

[11] Yılmaz S., Yazıcıŏlu O., Yılmaz M., Polat N. (2010a). Hirfanlı Baraj Gölü’nde yaşayan Cyprinus carpio L., 1758 ve Tinca tinca (L., 1758)'nın boy-ağırlık ve boy-boy ilişkileri ile mevsimsel kondisyon faktörleri, SDU Journal of Science (E-Journal), 5 (2) 154-162.

[12] Yılmaz S., Polat N., Yazıcıŏ̆lu O. (2010b). Samsun İli İçsularında Yaşayan Sazan (Cyprinus carpio L., 1758)'ın Boy-Ağırlık ve Boy-Boy İlişkileri. Karadeniz Fen Bilimleri Dergisi / The Black Sea Journal of Sciences. 1( 2).

[13] Buhan E., Aydın M., Akın Ş., Dal T. (2016). Almus Baraj Gölünde Yaşayan 9 Balık Türünün Boy-Ağırlık İlişkisi.Journal of Agricultural Faculty of Gaziosmanpasa University. 33 (2), 48-55.

[14] Birecikligil S., Çiçek E. (2011). Gaziantep İli Sınırları İçindeki Fırat ve Asi Havzası Akarsuları Balık Faunası. Biyoloji Bilimleri Araştırma Dergisi 4 (2), 29-34

[15] Uğurlu S., Polat N. (2007). Çakmak Baraj Gölü (SAMSUN) Balık Faunası. Fırat Üniv. Fen ve Müh. Bil. Dergisi (4), 443-448.

[16] Dönel K.E., Yılmaz E. (2016). Gaga Gölü (Ordu-Türkiye) Balık Faunası ve Tespit Edilen 4 Türün Morfometrik Karakterleri. Türk Denizcilik ve Deniz Bilimleri Dergisi 2 ( 2 ), 63-74.

[17] Bostancı D., Darçın M., Helli S. 2016. Yalıköy Deresi (Ordu) Balık Faunasının Tespiti Üzerine Bir Araştırma . Ordu Üniv. Bil. Tek. Derg., Cilt:6, Sayı:2, ,146-157/Ordu Univ. J. Sci. Tech., 6 (2), 146-157.

[18] Atıc1 T., Obalı O. (2010). The diatoms of Asartepe Dam Lake (Ankara), with environmental and some physicochemical properties Turk J Bot. (34), 541-548.

[19] Saylar Ö. (1997). Kastamonu Kabalar Gölet'indeki Cyprinus carpio (Linnaeus, 1758)'da Çeşitli Metotlarla yaş tayini. Kastamonu Eğitim Dergisi, 2 (3), 163-169.

[20] Chugunova N. I. (1963). Age and Growth Studies in Fish. National Science Foundation, 132 p, Washington.

[21] Bagenal T.B, Tesch F.W. (1978). Age and Growth. In: Methods for Assessment of Fish Production in Fresh Waters (Bagenal, T. B., Ed.), pp. 101-136, Blackwell Science Publication, Oxford, UK.

[22] Ricker W.E. (1975). Computation and interpretation of biological statistics of fish populations, Bulletin of the Fisheries Researh Board of Canada, 191: 1-382.

[23] Altındağ, N. 1991. Orta Anadolu Bölgesi sulak alanları ve işletmeye açılan barajların su kuşları ve balıklar açısından değerlendirilmesi. T.C. Başbakanlık Özel Çevre Koruma Kurumu Başkanlığı, Ankara

[24] Buyurgan, Ö., 2008. Asartepe Baraj Gölü (Ankara) 'nün Zooplankton Faunası Ve Mevsimsel Değişimi, Ankara Üniversitesi, Fen Bilimleri Enstitüsü, Yüksek Lisans Tezi, 88 sayfa, Ankara

[25] Çetinkaya S., Çınar Ş., Özkök R., Erol K.G. (2006). Beyşehir Gölü’ndeki sazan popülasyonu (Cyprinus carpio L., 1758)'nun büyüme özellikleri, I. Uluslar Arası Beyşehir ve Yöresi Sempozyumu, Konya, pp. 697-704.

[26] Yağc1 M., Uysal R., Yeğen V., Çetinkaya S., Cesur M., Bostan H., Yağcı A. (2008b). İznik Gölü (Bursa) sazan (Cyprinus carpio L., 1758) popülasyonunun bazı biyolojik özelliklerinin belirlenmesi, E. Ü. Su Ürünleri Dergisi, 25 (1), 19-25. 
[27] Yılmaz S., Yazıcıŏglu, O., Polat N. (2012). Bafra Balık Gölleri (Samsun, Türkiye)'ndeki Sazan (Cyprinus carpio L., 1758)'ın Yaş ve Büyüme Özellikleri Karadeniz Fen Bilimleri Dergisi 2 (7), $1-12$.

[28] Mert R, Bulut S. (2014). Some biological properties of carp (Cyprinus carpio L., 1758) introduced into Damsa Dam Lake, Cappadocia Region, Turkey. Pakistan J Zool., 46(2):337-346.

[29] Nikolsky, G.V. (1963). Ecology of fishes. Academic Press 352p. London.

[30] Özdemir N., Yılmaz F., Yorulmaz B. (2007). Dalaman Çayı Üzerindeki Bereket Hidro-Elektrik Santrali Baraj Gölü Suyunun Bazı Fiziko-Kimyasal Parametrelerinin ve Balık Faunasının Araştııılması ÇEV-KOR EKOLOJİ 16 (62), 30-36.

[31] Kara C., Alp A., Şimşekli M. 2010. Distribution of Fish Fauna on the Upper and Middle Basin of Ceyhan River, TurkeyTurkish Journal of Fisheries and Aquatic Sciences (10) 111-122.

[32] Berber S., Şaşı H., Topkara E.T., Cengiz Ö. 2011. Apolyont Gölü (Bursa) Balık Faunasının Belirlenmesi. İstanbul Üniversitesi Su Ürünleri Dergisi (26), 27-55.

[33] Dirican S., Çilek S. 2012. Identification of fish species of Çamlıöze Dam Lake, Sivas, Turkey. African Journal of Agricultural Research 7 (45), 6022-6026.

[34] Çoban M. Z., Gündüz F., Yüksel F., Demirol F., Yıldırım T., Kurtoğlu M. 2013. Uzunçayır Baraj Gölü (Tunceli) Balık FaunasıYunus Araştırma Bülteni. (2), 35-44.

[35] Güçlü S.S., Küçük F., Ertan Ö.O., Güçlü, Z. 2013. The Fish Fauna of the Büyük Menderes River (Turkey): Taxonomic and Zoogeographic FeaturesTurkish Journal of Fisheries and Aquatic Sciences (13), 685-698.

[36] Tanyolaç J. 975. Length-weght relationship and condition of carp, Cyprinus carpio Linnaeus, in Lake Mogan, Ankara. Communications de la Faculte des Sciences de L'Universite D'Ankara, Serie C 3, 19 (1), 1-12.

[37] Karataş M., Çiçek E., Başusta A., Başusta N. 2007. Age, growth and mortality of common carp (Cyprinus carpio Linneaus, 1758) population in Almus Dam Lake (Tokat-Turkey), Journal of Applied Biological Sciences, 1(3), 81-85.

[38] Kırankaya Ş.G., Ekmekçi F.G. 2004. Gelingüllü Baraj Gölü'nde yaşayan aynalı sazan (Cyprinus carpio L., 1758)'ın büyüme özellikleri. Turk J Vet Anim Sci. 28 (6), 1057-1064.

[39] Çolakoğlu S, Akyurt İ. 2011. Bayramiç Baraj Gölü'ndeki (Çanakkale) aynalı sazan (Cyprinus carpio L., 1758) balıklarının populasyon yapısı ve büyüme özellikleri. IÜ Su Ürün Derg. 26 (1), $27-46$. 